\title{
Correspondence
}

\section{Defect of neutrophil mobility with dominant inheritance in a family with Waardenburg's syndrome}

\section{Sir,}

Hayward et al. ${ }^{1}$ report an interesting family. They modestly conclude that the association may be coincidental, giving this possibility as much weight as of the two phenomena being linked. From the very informative pedigree (Figure repeated here, slightly altered for convenience) with the founder having had offspring by three wives, one can assess the odds against the association being chance.

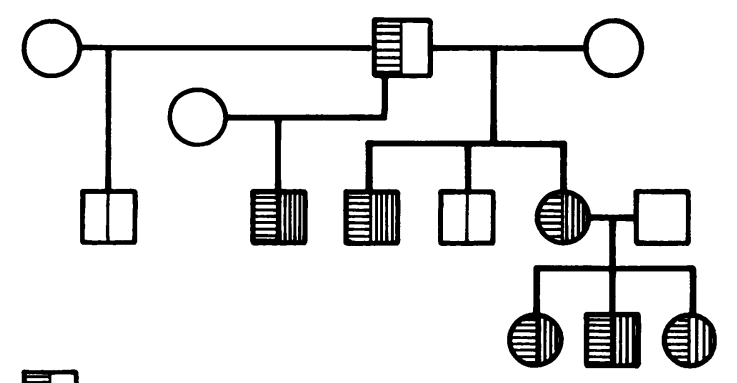

Waardenburg syndrome

Lazy neutrophil

Figure Coexistence of Waardenburg's syndrome and a defect of neutrophil mobility-family pedigree.

Each child of an affected person would have a 1 in 4 chance of inheriting both genes if they were unlinked, and a 1 in 4 chance of escaping both (possibilities $\mathbb{N}, \Delta, \mathbb{\Delta}, \mathbb{1}$ ).

The chance of the 8 informative children of affected individuals being concordant, either being free or of having both genes is thus $1 / 4^{8}$ or 1 in 65536 .

The chance that the genes are very closely linked is thus very great. All that needs explaining is the apparent normality of the founder's neutrophil function. Has this been tested?

A tendency to recurrent infections is not generally part of Waardenburg's syndrome. If a tiny deletion, invisible on current methods of chromosome analysis, were responsible for Waardenburg's, then perhaps a slightly larger one, possibly visible on methotrexate prometaphase banding, could be present in this family. The results of such study could be of value in identifying the chromosome which carries the Waardenburg gene. This approach has proved of value in the Wilms's tumour, aniridia, mental deficiency association syndrome. ${ }^{2}$

\section{References}

1 Hayward A R, Mowla R, Harvey B. Defect of neutrophil mobility with dominant inheritance in a family with Waardenberg's syndrome. Arch Dis Child 1981; 56: 279-82.

2 Rickardi V M, Sujansky E, Smith A C, Francke U. Chromosomal imbalance in the aniridia-Wilms' tumour association: 11p interstitial deletion. Pediatrics 1978; 61: 604-10.

M SUPER

Department of Clinical Genetics, Royal Manchester Children's Hospital, Jesson House, Manchester Road, Swinton, Manchester M27 IFG

Dr Hayward comments:

The founder died before 1960 and did not have neutrophil function tests; he did not have great susceptibility to infection. Descendants of the founder's great uncles were traced but none had either Waardenburg's syndrome or recurrent infections.

\section{T3 Uptake tests in newborn infants}

Sir,

Uhrmann et al. ${ }^{1}$ reported a high frequency of hypothyroxinaemia in low birthweight infants, particularly those with hyaline membrane disease and in small-forgestational age babies. Their findings are in accordance with other neonatal studies of serum thyroxine (and serum triiodothyronine) concentrations in recent years. ${ }^{2-5}$ A comprehensive assessment of the mechanisms for the low thyroid hormone concentrations in these infants has recently been given by Fisher and Klein. ${ }^{5}$

Uhrmann et al. ${ }^{1}$ excluded a decreased serum thyroid hormone binding capacity as the cause of the hypothyroxinaemia in low birthweight newborn infants. This conclusion was based on the T3 charcoal uptake test. However, the T3 uptake test is an indirect measurement of serum T4-binding capacity and, among other factors, depends not only on the serum level of thyroid hormonebinding proteins but also on the saturation of the binding sites of these proteins. Determinations of serum thyroxinebinding globulin (TBG) and thyroxine-binding prealbumin (TBPA) concentrations in healthy and sick newborn infants have shown a lower serum protein level in preterm 
and small-for-gestational age babies than in term ones, ${ }^{6}$ and pronounced alterations occur in preterm infants with idiopathic respiratory distress syndrome. ${ }^{3}$ Furthermore, calculations seem to indicate a lower saturation of the binding sites of serum TBG in healthy, low birthweight infants and in preterm infants with hyaline membrane disease compared with that of term infants during the first weeks of life. ${ }^{346}$

Although the T3 uptake tests may have clinical applications in infants, the T3 tests are sometimes difficult to interpret and do not elucidate the changes in serum thyroid hormone-binding protein concentrations in healthy and sick newborn infants of various maturities.

\section{References}

1 Uhrmann S, Marks K H, Maisels M J, Kulin H E, Kaplan M, Utiger R. Frequency of transient hypothyroxinaemia in low birthweight infants. Arch Dis Child 1981; 56: 214-7.

2 Jacobsen B B, Andersen H J, Peitersen A B, DigePetersen H, Hummer L. Serum levels of thyrotropin, thyroxine, and triiodothyronine in full term, small-forgestational age, and preterm newborn babies. Acta Paediatr Scand 1977; 66: 681-7.
3 Jacobsen B B, Peitersen B, Hummer L. Serum concentrations of thyrotropin, thyroid hormones, and thyroid hormone-binding proteins during acute and recovery stages of idiopathic respiratory distress syndrome. Acta Paediatr Scand 1979; 68: 257-64.

4 Jacobsen B B, Hummer L. Changes in serum concentrations of thyroid hormones and thyroid hormonebinding proteins during early infancy. Studies in healthy fullterm, small for gestational age, and preterm infants aged 7 to 240 days. Acta Paediatr Scand 1979; 68: 411-8.

5 Fisher D A, Klein A H. Thyroid development and disorders of thyroid function in the newborn. $N$ Engl $J$ Med 1981; 304: 702-12.

6 Jacobsen B B, Peitersen B, Andersen H J, Hummer L. Serum concentrations of thyroxine-binding globulin, prealbumin, and albumin in healthy fullterm, small-forgestational age, and preterm newborn infants. Acta Paediatr Scand 1979; 68: 49-55.

BENDT BROCK JACOBSEN
Department of Paediatrics $G$,
Rigshospitalet,
University of Copenhagen,
2100 -Copenhagen $\emptyset$, Denmark

\section{Book reviews}

Immunologic Disorders in Infants and Children, second edition. By E R Stiehm and V A Fulginiti. (Pp. 817; illustrated + tables. $£ 30.00$ hardback.) Saunders: Philadelphia. 1980.

This is the long awaited second edition of an excellent book which illustrates how widely immunology has permeated most areas of paediatrics. Today's medical student can no longer ignore the subject because immunological mechanisms seem to play such an important role in so many disease processes. The book is a major reference source-35 chapters written by more than $\mathbf{4 0}$ distinguished specialists. It is divided into three sections; the first deals with the development and function of the immune system, and contains an excellent review of the mucosal immune system by Hansen and Brandtzaeg - their clear account of normal mucosal physiology may help to promote understanding of some of the immunopathological disturbances which occur in gastrointestinal allergy and inflammatory diseases. The second section deals with the immunodeficiency disorders, an area which has grown enormously as knowledge of lymphocyte subpopulations and interactions has expanded. Defects are being defined at the molecular level (that is adenosine deaminase deficiency) rather than at cellular level, and newer treatments are appearing as the area of immunopharmacology grows. The immunodeficiency section will be outdated rapidly because monoclonal markers to lymphocyte subpopulations are already defining new defects. It is to be hoped that the gap between the second and the third edition will not be as great as that between the first two editions. The final section contains the organ specific chapters which indicate how immune mechanisms are concerned in most areas of paediatrics. No major system is excluded. Tumour immunology and transplantation are included here, and so too is the chapter on immunisation.

I recommend this book to every paediatrician; paediatric immunology is one specialty where a wide knowledge of general paediatrics is vital but equally no general paediatrician can afford to ignore the impact of immunology.

R J LEVINSKY

Retrolental Fibroplasia. A Modern Parable. By William A Silverman. Monographs in Neonatology Series. Series Editor T K
Oliver, Jr. (Pp. 246; illustrated + tables. $\$ 23.50$ hardback.) Grune \& Stratton: New York. 1980.

This modest volume is of profound importance for all doctors and for paediatricians in particular. The first half gives a historical account of the rise and fall of retrolental fibroplasia (RLF) as witnessed by the author who was intimately involved in the controversies and clinical trials of the early 1950s; this is enthralling and compelling reading. In relating the history of RLF, the author treats us to the history of the early development of neonatology including sketches of many of the most famous paediatricians of the day, such as Mary Crosse from Birmingham. We catch a glimpse of the desperate atmosphere of the early 1950 s as paediatricians and ophthalmologists searched for a cause for RLF and then had to face the apparent paradox that life-giving oxygen was, in some mysterious way, blinding premature babies.

Figure 7,2, which is perhaps the embodiment of all that the author is telling us, shows breathing patterns from a healthy, small, preterm infant in which 'the periodic' pattern of breathing in room air becomes 'regular' in $70 \%$ oxygen. $\mathrm{He}$ quotes from the authors of the study from 